\title{
Virus-Induced Cell Surface Antigens and Cell-Mediated Immune Responses
}

\author{
E. J. Shillitoe and F. Rapp
}

Department of Microbiology and Specialized Cancer Research Center, The Pennsylvania State University College of Medicine, Hershey, Pennsylvania 17033, USA

\author{
Introduction \\ Surface Antigens of Virus-Infected Cells \\ Influenza Virus \\ Antigenic Modulation \\ Surface Antigens of DNA Virus-Transformed Cells \\ SV 40 \\ Herpes Simplex Virus \\ Cytomegalovirus \\ Lymphocyte Responses to Virus Antigens \\ Lymphocyte Transformation \\ Lymphocyte Interferon Production \\ Macrophage Migration-Inhibition \\ Lymphocyte Cytotoxicity \\ Blocking of Lymphocyte Responses
}

Macrophage Responses to Viruses and Virus Transformed Cells

Conclusions

References

\section{Introduction}

The immune system of an infected host can recognize virus antigens on virus particles or on the surface of infected cells. Antigens can be classified as virion or nonvirion, depending on their presence in mature virus particles, and both types of antigen can appear on the surface of infected cells. In addition, virus-transformed cells can express virion and nonvirion antigens.

The host immune response to virus antigens has been under intensive study for many years and a number of immunity mechanisms have been described. Originally, virus immunity was equated with antibody production, but a number of observations are incompatible with such a simple correlation. For example, 
individuals with congenital antibody deficiency diseases are unusually susceptible to poliomyelitis, but are able to recover from other virus infections with life-long immunity. Those with normal antibody responses but deficient cell-mediated immunity are not particularly susceptible to poliomyelitis but are susceptible to vaccinia, herpes simplex, varicella-zoster, cytomegalovirus, and measles infections $[19,37,77,79,81]$. In experimental animals, passive transfer of antibody can cure advanced infections with yellow fever or coxsackie virus $[100,152]$ but in the case of herpes simplex virus infection, transfer of macrophages or $\mathrm{T}$ lymphocytes is required $[94,101]$.

Clearly, general statements cannot be made about the nature of virus-induced antigens, nor about which type of immune response is required for protection. Each virus infection has to be examined individually. Other chapters in this volume describe virion antigens and the various components of the humoral immune system. A comprehensive survey of surface antigens of virus-infected cells was presented recently by Burns and Allison [12], and this chapter will examine in detail a few selected topics on which current research is focused.

\section{Surface Antigens of Virus-Infected Cells}

\section{Influenza Virus}

In most cases little is known about the surface antigens of virus-infected cells. The existence of the antigens can be inferred from immunologic studies in vitro and in vivo, but their chemical nature has not always been clarified. However, in the case of influenza viruses, the cell-surface antigens which they induce have been isolated and studied in detail. An understanding of these antigens is important in understanding the epidemiology and immunology of influenza, and therefore will be considered here in some depth.

Cells infected by influenza viruses synthesize at least nine viral glycoproteins, two nonstructural and seven structural. Of the structural proteins, three are found on infected cell plasma membranes and on the virion surface, and four are internal proteins [147].

Influenza viruses can be classified into types $\mathrm{A}, \mathrm{B}$, and $\mathrm{C}$ on the basis of typespecific antibody to the internal ribonucleoprotein and matrix protein. This antibody appears after infection but is not correlated with immunity. The surface proteins associate on the virion envelope and on the infected cell membrane where they can be detected $4 \mathrm{~h}$ after infection by immunofluorescence techniques $[45,74]$ and antibody-mediated cell lysis [11]. The surface proteins as seen by electron microscopy are in the form of spikes, and consist of either neuraminidase or hemagglutinin. Both are antigenic, but protective immunity against influenza is due principally to immune responses against the hemagglutinin $[56,112]$. The hemagglutinin spike is comprised of two glycopeptides, $\mathrm{HA}_{1}$ and $\mathrm{HA}_{2}$, linked by disulfide bonds, and these pairs associate as trimers to form the spike. $\mathrm{HA}_{1}$ is the principal antigen since it can serve as an immunogen for preparing hemagglutination-inhibiting antibody and also can absorb the antibody from immune sera [29]. 
An important property of the hemagglutinin and neuraminidase antigens is their instability and antigenic changes. Major changes in the hemagglutinin are known as 'antigenic shift' and are the result of substantial changes in amino acid sequences in $\mathrm{HA}_{1}$ and $\mathrm{HA}_{2}[69]$. These changes result in influenza pandemics since the population has not been naturally immunized against the new antigenic determinants. Minor changes in amino acid sequence occur between pandemics and cause slight antigenic changes: this is 'antigenic drift.' Influenza $\mathrm{A}$ is the only type that causes pandemics in man, and so has been studied in the most detail. The first human influenza virus was isolated in 1933 and its hemagglutinin and neuraminidase antigens have been designated HON1. A variant isolated in 1947 was believed, probably incorrectly, to show a distinctive change in the $\mathrm{H}$ antigen and was designated H1N1. A new pandemic strain appeared in 1957, apparently from Asia, in which both the $\mathrm{H}$ and $\mathrm{N}$ surface antigens were different from the earlier strain, and this was termed $\mathrm{H} 2 \mathrm{~N} 2$. This virus showed antigenic drift until 1968 when the Hong Kong subtype appeared. The $\mathrm{N}$ antigen in this was unchanged but the $\mathrm{H}$ antigen was new, and the virus was classified as H3N2. This virus is still in circulation in man, although showing frequent antigenic drift. The $\mathrm{H} 1 \mathrm{~N} 1$ and $\mathrm{H} 2 \mathrm{~N} 2$ strains disappeared from the population when the subsequent strains developed, although the H1N1 strain has now re-emerged, and has caused a recent epidemic in Russia [149].

The mechanism by which influenza A viruses become antigenically altered is unknown, although two principal hypotheses have been advanced. The first is that mutations occur and the new strain emerges by natural selection and growth in the nonimmune population. This is probably the mechanism of antigenic drift although no experimental evidence for such a process has been obtained. On the other hand, antigenic shift may involve participation by animal viruses. It is well established that species such as horses, ducks, and pigs have their own influenza viruses which belong to the same group $\mathrm{A}$ as human viruses. The $\mathrm{H}$ and $\mathrm{N}$ antigens of animal influenza viruses are usually different from those of man, but the hemagglutinin of the human Hong Kong strain, H3, was found by Laver and Webster [69] on influenza viruses isolated from ducks in the Ukraine and from horses in Miami, both in 1963. This was five years before $\mathrm{H} 3$ had been found on a human influenza virus. Transmission from animals to man was observed in 1975 and 1976 when the swine influenza virus, Hsw1N1, was isolated from farm workers and soldiers at Fort Dix, New Jersey [134]. At the time, a similarity was noted with the origin of the 1918 pandemic which started at an army camp housing many young farm workers. A swine flu pandemic was therefore widely forecast in 1975-76 but failed to materialize.

As well as direct infection by animal viruses, it is possible that antigenic shift could happen by recombination between human and animal influenza viruses. Experimentally it has been shown that simultaneous infection of an animal with two different influenza $A$ viruses can result in antigenic recombination and production of a new variant [145] (Fig. 1). It is therefore possible, although unproven, that this is the origin of new pandemic influenza strains.

Cell-mediated immune responses to influenza viruses have been demonstrated by three in vitro techniques. Lymphocytes from sensitized mice and guinea pigs undergo blastogenesis and produce migration inhibitory factor (MIF) on exposure 

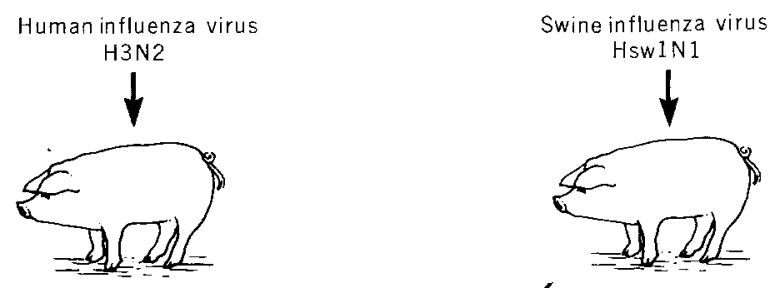

$\searrow$

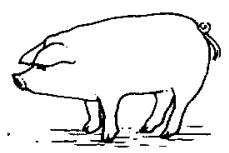

Contact pig acquires both viruses

by natural transmission

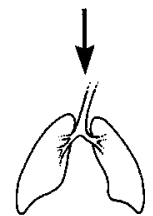

Virus RNA segments are

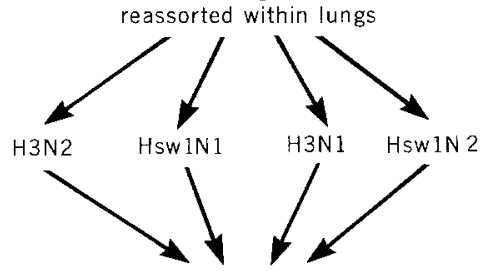

Antibodies to Hsw 1 and $\mathrm{N} 2$

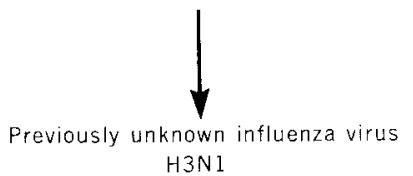

Fig. 1. Experiment by Webster et al. [145] demonstrating recombination of human and swine influenza viruses to produce a virus with a new combination of hemagglutinin and neuraminidase antigens. The 'new' virus was also shown to be pathogenic and transmissible in a stable form

to influenza virus $[35,38,48,146]$. Cytotoxic responses can also be measured since T lymphocytes from mice infected with influenza virus will lyse infected target cells. If the target cell is permissive for influenza virus, the lymphocytes will only lyse targets infected with virus of the identical hemagglutinin subtype [33]. However, when the target cells are relatively nonpermissive, the lymphocytes show much less specificity. When the animal is infected with an influenza virus type $\mathrm{A}$ with known $\mathrm{H}$ and $\mathrm{N}$ antigens, the $\mathrm{T}$ cells will lyse targets infected with type $\mathrm{A}$ showing different $\mathrm{H}$ and $\mathrm{N}$ antigens but will not lyse cells infected with type $\mathrm{B}[31,153]$. The nature of the 
common type A antigen which the $\mathrm{T}$ lymphocytes recognize is unknown. An obvious candidate is the matrix protein which is shared by all influenza viruses of one type, but is not believed to be expressed on cell surfaces [16]. An alternative explanation is that since the cytotoxic response is maximal at five days after infection, the specificity of the $T$ cell receptor might be less restricted at that time; indeed, early blastogenic responses in humans are not highly specific [24], and early $\operatorname{IgM}$ antibody is less specific than late $\operatorname{IgG}$ which is used to define influenza strains [110]. Whatever the explanation, the fact remains that immunity to infection is dependent on prior exposure to the same subtype and is not induced by exposure to other subtypes. Therefore, the in vivo significance of cross-reacting cy totoxic $T$ cells remains to be determined.

\section{Antigenic Modulation}

Since most viruses carry antigens that elicit a strong immune response in the host, it is unclear why certain infections can become persistent or recurrent. One possible explanation lies in specifically induced unresponsiveness of the host, as described later. Another possibility is that the virus antigens may be concealed or lost.

Loss of a cell surface virus antigen was first demonstrated with the thymusleukemia (TL) antigen following exposure to specific antibody. The TL antigen occurs naturally on mice thymocytes of certain strains $(\mathrm{TL}+)$ and not of other (TL -) strains. The TL antigen can appear on leukemic cells from either TL + or $\mathrm{TL}-$ mice, and when TL + leukemias are passed in isogenic $\mathrm{TL}-$ mice immunized against the antigen, the cells continue to multiply, but become TL - . If the cells are then passed in nonimmunized hosts the antigen reappears, showing that its loss was not due to selection of a TL - clone of cells. Since the immunized TL - mice produce anti-TL antibody, it was considered that the reversible loss of antigen might be mediated by the antibody, and a series of experiments confirmed this $[10$, 95]. When TL + cells were exposed to TL antibody in vitro over a wide range of concentrations, loss of antigen could be demonstrated by a cytotoxicity test within $10 \mathrm{~min}$, and was complete within an hour. The cells initially were sensitized to complement by contact with antibody, but then lost both the sensitivity to complement lysis and the sensitivity to TL antibody with complement. An immunofluorescent study by Stackpole et al. [124] showed that following modulation, the antigen had been displaced into patches or caps on the cell surface, whereas before modulation it had been distributed evenly. Some antigen-antibody complexes were internalized by the cell, and it was noted that the process of capping after internalization resembled the cap formation and internalization of immunoglobulin from the surface of B lymphocytes, due to specific anti-immunoglobulin sera [129].

Herpes simplex virus antigens may also be modulated in vivo. Stevens and Cook [127] found that when nerve ganglia which harbored latent herpes simplex were transplanted to recipient animals having antibody to the virus, the antibody prevented the reappearance of virus antigen and of infectious virus. Infected ganglia transplanted to normal (nonimmune) mice yielded virus antigens and infectious virus following induction procedures. It was suggested that virus latency is maintained by antigenic modulation. 
Studies of measles virus by Oldstone and colleagues $[54,63,96]$ have clearly demonstrated the sequence of events when measles virus-infected cells are exposed to measles antiserum. Initially, a polyvalent antibody will cross-link the antigen molecules, which become redistributed on the cell surface in a discontinuous manner. The 'patches' of antigen then gather together at one pole of the cell in a 'cap', and this process is dependent on both temperature and active cell metabolism [54]. When surface antigens of uninfected cells are capped by antibody the cap is lost, largely by endocytosis, leaving the cell surface temporarily free of that antigen [139]. In the case of measles-infected cells the measles antigen is also lost, although electron microscopy studies have not observed endocytosis [63]. Presumably, the antigen-antibody complex is shed from the cell surface. In any event, the infected cell is left without virus antigen and as a result, is no longer susceptible to lysis either by antibody with complement or by sensitized lymphoid cells [96].

The mechanism by which modulation of virus antigens occurs in vivo is not known: possibly, the concentration of antibody required for modulation is low and cells could be protected before lytic concentrations are reached. A possible example of measles virus antigen modulation in vivo may have occurred during the experiments of Wear and Rapp [44] and Albrecht et al. [2]. They were able to initiate a persistent infection with measles virus by introducing the virus into the experimental host together with antibody. If virus was injected by itself, the host rapidly aliminated the infection. In man, it is possible that persistent infections by viruses such as measles, rubella, herpes simplex, and cytomegalovirus could be due, at least in part, to antigen modulation.

Virus-induced antigens of virus-transformed cells may be lost spontaneously. Albrecht and Rapp [1] showed that human cytomegalovirus antigens were detectable on the membrane of $47 \%$ of hamster cells transformed by that virus, but that after the cells had been passaged in hamsters, the percentage had fallen to $17 \%$. This might be related to the loss of virus gene sequences during repeated division of the cells: Minson et al. [82] showed that about $40 \%$ of the genome of herpes simplex virus type 2 was present in cells transformed by that virus at passage 48 , but by passage 78 , this had decreased to less than $10 \%$.

\section{Surface Antigens of DNA-Virus-Transformed Cells}

\section{SV40}

One of the most closely studied tumor viruses is simian virus 40 (SV40). Isolated originally by Sweet and Hilleman [128] from cultures of monkey kidney cells, this virus causes productive infection and lysis of monkey kidney cells, although it can transform nonpermissive rodent cells. Injection of SV40 into newborn hamsters causes in vivo cell transformation and development of tumors $[30,42]$. Several antigens can be identified in cells infected with SV40. The $V$ antigen is a viral capsid antigen and is found only in productively infected cells. All the other antigens have been found in infected permissive and nonpermissive cells. The $T$ antigen is found in the nucleus, the $U$ antigen is associated with the nuclear membrane, and the 
transplantation and surface antigens are found on the cell surface and so will be considered in some detail.

The existence of a tumor-specific transplantation antigen (TSTA) on cells transformed by SV40 was inferred from transplantation studies in 1963 [20, 44, 55, 58 ]. It was found that if an animal was immunized with the virus or with virustransformed cells, it became resistant to an SV40-induced transplantable tumor. The virus specificity of the system was shown by the lack of protection in animals given cells transformed with polyoma virus [120]. Virus specificity rather than host specificity was also indicated by the rejection of transplantable tumors if the animals had been immunized with transformed cells or tumor cells produced by the same virus but from a different species. Adult hamsters can be immunized against SV40 tumor cells by injection of membranes from SV40 tumor cells [17] which indicates that the antigen is on the cell surface. This conclusion is supported by in vitro tests of tumor immunity discussed elsewhere in this review.

Although the SV40 transplantation antigen is virus-specific, it has not been shown whether it is coded for by the virus, is a derepressed cellular protein, or is a hidden component of the normal cell membrane which is revealed by virus infection. This antigen has not been chemically purified and the only technique for demonstrating its presence is the tumor rejection test. SV40-specific antigens can also be detected on cells transformed by $\mathrm{SV} 40$ by the immunofluorescence techniques [132], mixed hemadsorption [47], serum-mediated colony inhibition [131], and serum-mediated cytotoxicity [122], but the relationship of the serologically defined antigen to TSTA is unclear. In addition, an antigen has been detected by mixed hemadsorption on SV40-transformed, polyoma-transformed, and spontaneously transformed cells [47]. This antigen may be a normal cellular antigen, since it can be exposed on many cell types by treatment with trypsin. It is, however, not involved in tumor rejection by immunized animals, since SV40 and polyoma TSTA do not cross-react in in vivo tests [120]. An embryonic antigen can also be detected on the surface of cells transformed by SV 40 and other viruses $[27,136]$ but it remains doubtful whether immune responses against the embryonic antigen play any part in tumor immunity.

\section{Herpes Simplex Virus}

Cells infected or transformed by herpes simplex virus (HSV) express HSV antigens on the cell membrane. Immunofluorescent staining of cells infected with HSV can be demonstrated $4 \mathrm{~h}$ after infection [52] and complement-dependent lysis by HSV antiserum can be detected six hours after infection [11]. The HSV antigen is not localized at specific sites on the cell membrane, but is evenly distributed over the cell surface [113]. A variable proportion of cells transformed by partially-inactivated HSV can be shown to carry HSV cytoplasmic antigens by immunofluorescence. A cell surface antigen probably exists as well, since in vitro tests have shown lymphocyte cytotoxicity [65]. Virus-specific transplantation antigen analogous to that of the other transforming DNA viruses has not been demonstrated; however, animals immunized with HSV-transformed cells or with infectious virus are not protected against subsequent challenge with the transformed cells $[26,67,133]$. The reason for this curious finding is unknown. The transformed cells probably carry 
some foreign antigens since nonspecific immune stimulation can protect animals from transplanted cells to a slight extent [133].

\section{Cytomegalovirus}

Cells transformed by human cytomegalovirus (CMV) express CMV antigens on the membrane; these have been detected by lymphocyte cytotoxicity tests [90] and also by the techniques of mixed hemagglutination and ${ }^{125}$ I-labeled antiglobulin [66]. As in the case of HSV-transformed cells, these surface antigens are not analogous to the TSTA of SV40 and it has not proven possible to protect animals against isografts of CMV-transformed cells by preimmunization either with virus, transformed cells, or cell extracts.

\section{Lymphocyte Responses to Virus Antigens}

\section{Lymphocyte Transformation}

When lymphocytes are cultured in the presence of an antigen to which they have been previously sensitized, DNA synthesis increases and the cell enlarges and 'transforms' into a lymphoblast. This process can be quantitated by measuring the uptake of radiolabeled thymidine and is used extensively in the study of cellmediated immunity.

During a primary infection with HSV, the lymphocyte transformation response is already maximal at the time of diagnosis and falls away in the following 2-3 weeks [116]. This response then remains detectable, but at a low level, indefinitely. If the patient has a recurrent herpetic infection, some laboratories have reported a transient increase in the response at that time $[108,115]$ although others have found no change $[103,125]$. The lymphocyte subpopulation which responds to the virus antigen in this test appears to be the $T$ cell; however, a standard technique for the isolation of $T$ cells involves removal of other cell types by nylon-wool columns. Recently it has been found that soon after immunization against foreign red cells, sensitized T lymphocy tes of mice become nylon-adherent [18]. Shillitoe et al. [117] have found that nylon-wool-separated $T$ cells from patients with primary or recurrent HSV infections are unresponsive to HSV antigens at the time of the infection and that this can be attributed to retention of HSV-responding cells by the column. The mechanism by which this occurs is unknown but may be related to the acquisition of an $\mathrm{Fc}$ receptor by activated $\mathrm{T}$ cells. If that is the case, then the effect will not be specific for HSV but will be found in T cells responding to other viruses as well. The nylon-wool purification technique could therefore lead to an important and previously unrecognized artifact in the study of cell-mediated immunity to viruses.

Experimentally, immunization of rabbits to HSV can sensitize their spleen cells or peripheral blood lymphocytes to respond by thymidine incorporation within three days, although serum antibody is not detectable for another four days [106, 107]. Similarly, in guinea pigs, Scriba [114] found lymphocytes sensitized to HSV between one and three weeks after immunization. Lymphocyte transformation can be elicited by cell-bound HSV antigen [107] but soluble HSV antigen can be equally antigenic and immunogenic [148]. 
Lymphocyte transformation in response to virus antigens has been observed in the case of numerous other viruses, including CMV [86, 130], Epstein-Barr [41, 130], vaccinia [106], varicella-zoster [109], rubella [119], and mumps virus [123]. In these cases the pattern of response is similar to that described for HSV : a response to the virus is found at the time of an acute infection and declines during convalescence but remains at a detectable level thereafter. Lymphocyte transformation is therefore an indicator of sensitization to virus antigens, and lymphocyte multiplication will expand the clone of cells which are sensitized to the stimulating antigen. However, it does not, by itself, indicate an antiviral mechanism. Antiviral activity can be assessed by other tests of cell-mediated immunity such as production of soluble mediators.

\section{Lymphocyte Interferon Production}

When lymphocytes from patients with recurrent herpetic infection were cultured in the presence of HSV antigen, antiviral activity appeared in the supernatant if the patient had had a herpetic lesion between two and six weeks previously [103]. The antiviral effect reached the highest level in those patients who tended to show the longest interval before the next recurrence and was specific in that it was not elicited by vaccinia virus. This effect was assumed to be due to interferon, but later work showed that interferon produced by antigen-stimulated lymphocytes differs from classical interferon since it is unstable at $\mathrm{pH} 2$ and at $56^{\circ} \mathrm{C}$, and is relatively unaffected by antiserum to classical interferon. It is apparently produced by $\mathrm{T}$ lymphocytes [141, 142], although leukocyte interferon (a subclass of classical interferon) is also synthesized by these cells.

Interferon was shown by Lodmell and Notkins [73] to be produced by rabbit leukocytes sensitized to PPD and stimulated with PPD or by leukocytes sensitized and then stimulated by HSV. Peritoneal exudate cells were more effective than spleen cells in each case, suggesting that macrophages were important in the response. The supernatant fluid from as few as one sensitized leukocyte per 200 rabbit kidney cells could inhibit HSV replication by over $90 \%$. Immune complexes consisting of HSV antigen and anti-HSV antibody were also capable of stimulating sensitized lymphocytes to produce interferon [36]. The role of interferon in the control of virus infections is considered in more detail in Chapter 3.

\section{Macrophage Migration-Inhibition}

There is evidence suggesting that considerable interaction occurs between $1 y m$ phocytes and macrophages in vivo. Data from in vitro assays support these in vivo observations. Macrophage migration-inhibition is a convenient assay and measures the release of MIF from presensitized lymphocytes, on contact with the specific antigen. MIF inhibits the migration of macrophages from capillary tubes in vitro, and in vivo it probably restricts macrophages to the site of the immune response. In addition, MIF or another moiety activates macrophages [92] which show a variety of changes including increased antiviral activity.

Following immunization, animals develop a positive migration inhibitory response to influenza $[13,104,143]$, rubella $[88]$, and herpes simplex viruses $[61$, 
80] after about seven days. Development of a migration inhibition response to HSV is associated with the ability of spleen cells to restrict the spread of the virus from cell to cell in a monolayer [118]. In man, a positive macrophage migration-inhibition response to HSV develops during recovery from primary herpetic infection [116] and recurrent infections with the virus may be due to an inadequate production of MIF by T lymphocytes $[115,117]$. O'Reilly et al. [97] have demonstrated that lymphocytes from patients with recurrent herpetic infections are relatively unresponsive in a similar test of cell-mediated immunity: leukocyte migrationinhibition. Responses to measles virus can also be detected by migration-inhibition assays and Utermohlen and Zabriskie [140] have found this response to be decreased in patients with multiple sclerosis. However, other workers have not been able to confirm the specificity of this finding [93].

Virus-specified tumor antigens can be detected in vitro by macrophage migration-inhibition tests. Blasecki and Tevethia [9] immunized mice with SV40 so that they became specifically immune to transplanted syngeneic SV40-transformed cells. The peritoneal exudate cells then showed a positive response in the direct migration-inhibition test to a soluble tumor-specific antigen derived from cells transformed by SV40. When newborn hamsters were inoculated with SV $40,80 \%$ eventually developed tumors and peritoneal exudate cells from the tumor-bearing animals did not respond to the SV40 tumor-specific antigen. However, cells from the tumor-free animals did respond to the antigen suggesting that migration-inhibition is a valid in vitro test of tumor immunity. Similar results were reported by Halliday [46], who found that mice with progressing Moloney virus-induced sarcomas did not respond to tumor antigen, while those with regressing tumors were responsive. The antigen used by Blasecki and Tevethia [9] was not fully characterized, but experimental results with the migration-inhibition test suggest that it might be the SV40 TSTA, for which no other in vitro assay exists.

\section{Lymphocyte Cytotoxicity}

Target cells infected with or transformed by a virus and expressing virus antigens can be lysed by sensitized lymphocytes in vitro. Lysis can be recognized in two ways. In the microcytotoxicity assay the target cells are dispersed on the floor of a tissue culture dish: after incubation with lymphocytes the surviving target cells are stained and counted visually. In chromium release assays, the target cells are labeled with

${ }^{51} \mathrm{Cr}$ and release of this radioisotope in the presence of the lymphocytes is used to calculate the percentage of lysis by one of several formulas.

The best characterized assay is that using $\mathrm{Cr}$ release, where it has been shown in animal experiments that the effector cell, in a short-term test, is the T lymphocyte [14]. With virus-infected or -transformed target cells, it has become clear in recent years that specific lysis of the targets by $T$ cells is related not only to the virus antigen on the cell surface, but also to the histocompatibility antigens [22].

The system of histocompatibility antigens which is best characterized is the $\mathrm{H}-2$ system of mice [57]. The H-2 antigens, which are glycoproteins, are found on the surface of most cells and are coded for by a gene complex on murine chromosome 17. Two of the antigens are coded for at either end of the $\mathrm{H}-2$ gene complex and are termed H-2K and H-2D. Since an outbred mouse has two different chromosomes 
17 , it has two antigens of the $\mathrm{H}-2 \mathrm{~K}$ region and two of the H-2D region: one of each inherited from each parent. The antigens specified by the two regions are distinct from each other and the total number of antigens throughout the species may be well over 100. By intensive inbreeding, a number of inbred lines of mice have been developed that are relatively homogeneous antigenically and so can be used for research into histocompatibility. In man, the histocompatibility system is less well defined. However, it is known that the analogous system, termed the HLA gene complex, is located on chromosome 6 and has four loci designated A, B, C, and D, which code for histocompatibility antigens [28]. Both HLA and H-2 antigens contain a light polypeptide chain in common, known as beta-2-microglobulin. It is approximately 100 amino acids long and closely resembles the constant region of human and mouse antibody molecules. The similarities between the mouse $\mathrm{H}-2$ and the human HLA systems suggest that they are closely related and serve the same biologic functions. Investigations of the mouse system are therefore probably applicable to man in many ways.

The original observation of the importance of histocompatibility antigens in cytotoxic responses in this field were made by Zinkernagel and Doherty [150]. They showed that mouse cells infected with lymphocytic choriomeningitis virus (LCM) were lysed by $T$ cells from mice infected with that virus and not other viruses, but if the target cells were of type H-2k, the cytotoxic T cells had to be H-2k for lysis to occur. Similarly, if the infected target cells were $\mathrm{H}-2 \mathrm{~d}$, they were only lysed by T cells bearing $\mathrm{H}-2 \mathrm{~d}$, and not by those bearing $\mathrm{H}-2 \mathrm{k}$. By studying a variety of inbred mouse strains and target cells of various histocompatibility types, they showed that the non- $\mathrm{H}-2$ genetic background, the $\mathrm{M}$ locus, and other $\mathrm{H}-2$ specificities are not relevant, and that genes in the I region play little or no part in regulating the phenomenon [23]. A similar histocompatibility restriction has been reported for ectromelia virus [7, 39], vaccinia virus [59, 60], and HSV [98].

A histocompatibility requirement for $\mathrm{T}$ cell-mediated lysis has also been observed using virus-transformed cells. Blank et al. [8] showed that T cells from mice immunized with syngeneic Friend virus-induced tumor cells showed cytotoxicity for tumor cells specific not only for the virus-associated antigens but also for the $\mathrm{H}-2$ antigens. Similar observations have been made using SV40-transformed target cells [137].

The mechanism by which histocompatibility is required for T cell-mediated lysis has been studied closely. It is thought that there are two possible mechanisms by which the phenomenon can occur. The T cell could have two receptors, one for the 'self' antigen and one for the virus antigen (Fig. 2 a), and binding of both receptors would be necessary for cytotoxicity. Alternatively, the $\mathrm{T}$ cell might have just one receptor, which would recognize a modified self antigen (Fig. 2 b). An extreme version of the second alternative is that the infectious process results in expression of a cryptic host gene and that reactivity is directed only against an abnormally expressed alloantigen [40]. Although few studies on the $T$ cell receptors have been carried out, the question has been approached experimentally by examining the surface of the infected target cells by co-capping experiments (Fig. 3).

If virus and $\mathrm{H}-2$ antigens are not physically associated, then capping of one by antibody will not co-cap the other (Figs. 3 a and 3 b). If they are associated, the capping of one will cause redistribution of the other (Figs. $3 \mathrm{c}$ and $3 \mathrm{~d}$ ). One antigen 
(a)

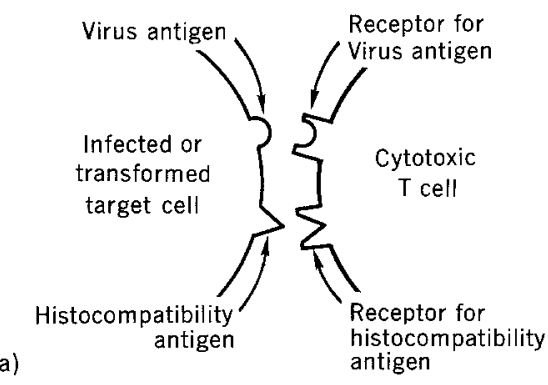

(a)

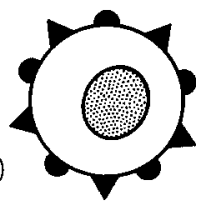

(c)

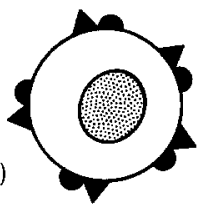

T cell

(b)

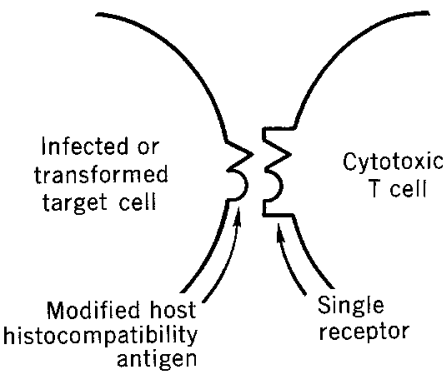

(b)

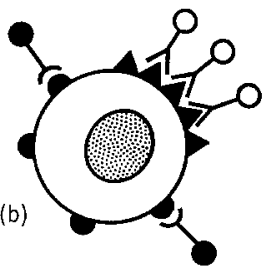

(d)

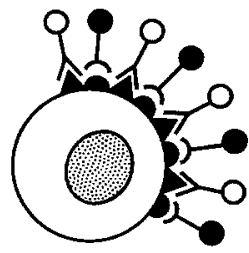

Fig. 2. Two possible explanations for histocompatibility restriction of T cell-mediated cytotoxicity. In (a) $T$ cells have two receptors, one for histocompatibility and one for virus antigen. Simultaneous binding of both receptors is necessary for cytotoxic activity of the lymphocyte. In (b) the virus infection causes modification of a host histocompatibility antigen and lymphocytes recognize the modified antigen

Fig. 3. If $\mathrm{H}-2$ and virus antigens are not physically associated on the cell surface (a) then capping of one will not cap the other (b). If H-2 and virus antigens are physically associated (c) then they will co-cap (d). The two antigens can be localized visually by labeling the antisera used to cap them with dyes that fluoresce in different colors

can be stained by antiserum conjugated with rhodamine and the other antiserum can be conjugated with fluorescein; under ultraviolet illumination these can be easily distinguished since one will appear red and the other green.

This experiment was performed by Schrader et al. [111] using mouse tumor cells expressing Rauscher leukemia virus antigens. Anti- $\mathrm{H}-2 \mathrm{~d}$ and anti- $\mathrm{H}-2 \mathrm{~b}$ sera were raised by immunization of mouse strains not carrying these specificities and antiserum to the virus protein gp69/71 was raised in goats. It was shown that patching and capping of the $\mathrm{H}-2$ antigens resulted in co-patching and co-capping of the virus antigen as illustrated in Fig. $3 \mathrm{~d}$. Equally, capping of the virus antigens resulted in co-capping of the $\mathrm{H}-2$ antigens [111]. It was concluded that $\mathrm{H}-2$ and virus antigens are physically associated on the cell surface. This conclusion was supported by a blocking experiment. Cytotoxic syngeneic lymphocytes sensitized against the virus antigens lysed the cells. This could be blocked by pretreating the cell with anti-H-2 serum of the appropriate specificity. The blocking experiment shows that binding at two sites is necessary but does not show whether they are physically associated.

On the basis of these observations, Schrader et al. [111] proposed that H-2 molecules serve as adaptors that combine with virus antigens on the cell surface to 
form hybrid antigens containing elements of self ( $\mathrm{H}-2)$ and non-self (virus) antigens (Fig. 2 b). This adaptor-antigen complex may then be recognized by a subclass of $T$ lymphocytes that possess a repertoire of receptors for hybrids of foreign and $\mathrm{H}-2$ antigens.

Histocompatibility types may also determine the resistance of animals to various viruses, although the mechanisms are unclear. Lopez [76] identified several strains of mice resistant or susceptible to HSV but could not relate this to the $\mathrm{H}-2$ type. In contrast, Chalmer et al. [15] found that resistance to murine CMV was greater in mice possessing the $\mathrm{H}-2 \mathrm{k}$ allele. Lilly [71] showed resistance to viral leukemogenesis was also linked to $\mathrm{H}-2$ type. Resistance to the oncogenic effect of another herpesvirus, Marek's disease virus, has also been found associated with the major histocompatibility complex in its natural host the chicken [75]. The H-2 gene complex is closely associated with the Ir complex which controls immune responses to several known antigens, and so it seems probable that resistance to these herpesviruses in different histocompatibility groups is determined by the immune response.

In man, several reports have failed to find a requirement for histocompatibility between effector and target cells in the case of measles [62], mumps [3], rubella [105], CMV [135], influenza [43], and HSV [125]. Indeed, in some cases, the target cells have been from another species and cytotoxicity has still occurred. However, it has usually not been established that the effector cells were $\mathrm{T}$ lymphocytes. Unlike the mouse, there is no anti-T cell antiserum for use with human cells so it can be difficult to separate $\mathrm{T}$ cell cytotoxicity from that due to antibody-dependent cytotoxic cells [102]. Those cells can acquire antibody passively and very extensive washing is required to remove it [87].

There is some preliminary evidence that purified $\mathrm{T}$ cells from patients with infectious mononucleosis will only kill target cells carrying both Epstein-Barr virus (EBV) antigens and HLA antigens [138] but no correlation was established between the HLA type of the effector and target cells. Ewan and Lachmann [34] showed killing of measles virus-infected human cells by sensitized human $\mathrm{T}$ lymphocytes and examined the HLA antigens of the targets and effectors: no correlation between the two was necessary for cytotoxicity to occur.

The histocompatibility requirement for $T$ cell-mediated cytotoxicity has therefore been demonstrated convincingly in mice, but in other species the phenomenon is less well established.

\section{Blocking of Lymphocyte Responses}

The blocking of lymphocyte functions by various serum factors was first studied in relation to cytotoxic responses to tumor cells [49]. It was shown in a number of animal systems that lymphocytes from tumor-bearing animals could kill the tumor cells in vitro but that this effect could be inhibited by the animal's own serum. The cytotoxic effect was usually not blocked by serum from a tumor-free, tumorimmune animal. In the case of virus-induced tumors, there is now evidence that the blocking effect can be mediated in several ways. Antibody can block at the target cell level by coating the antigenic sites of the target cell and so preventing recognition by lymphocyte receptors. This has been shown by Murasko and Lausch [91] in the 
case of CMV-transformed and CMV-infected target cells. Similarly, the killing of HSV-transformed cells by HSV-sensitized lymphocytes is blocked by HSV antiserum [65]. The blocking factor in these experiments was probably antibody, since it bound specifically to the target cells and not to the lymphocytes, and it could not easily be washed of the cells. The blocking factor could be removed from the serum by absorption with cells carrying the homologous antigen, but not by absorption with other cells. These experiments indicated the presence of antibody in the blocking factor, but did not exclude the possibility of it being an antigenantibody complex. Antibody does not block in all cases since SV 40 antiserum was not shown to block killing of tumor cells by SV40-sensitized lymphocytes [68].

Serum blocking activity has been correlated with the appearance of tumors in animals given polyoma or Rous sarcoma virus [121]. Passive transfer of serum with blocking activity can enhance the growth of polyoma tumor isografts [5] and passive transfer of a serum factor antagonistic to the blocking factor can cause regression of polyoma tumor metastases [6].

Virus-associated antigen can also block lymphocyte cytotoxicity, but unlike antibody, the antigen blocks the lymphocytes themselves, presumably by occupying antigen receptors. Antigen released from the surface of cells transformed by the SV40-adenovirus hybrid specifically blocked sensitized lymphocytes [99]. When SV40 antibody was added to the antigen, the complexes still blocked, but by binding to the target cells and not to the lymphocytes [99]. When the degree of blocking was assessed at the effector cell level, a dose dependent effect was observed. The more antibody was added to the antigen, the greater the degree of blocking, until a point was reached where addition of further antibody actually increased cytotoxicity. The cytotoxic response in the presence of complexes in antibody excess was, however, not specific for the type of target cell, since all other cell types tested were also killed. Subsequent experiments demonstrated that the complexes in antibody excess stimulated macrophages, and these became the cytotoxic cell when the lymphocytes were blocked (Prather et al., in preparation).

Although blocking of lymphocyte responses to the antigens and virustransformed cells is a well established phenomenon, much less is known about blocking of cell-mediated responses during acute virus infections. Hyperimmune antiserum to HSV can inhibit lymphocyte transformation in response to cell-bound HSV antigens [107] but during naturally occurring infections, the antibody response is insufficient to block the lymphocytes $[32,115]$. The response of rabbit lymphocytes to rubella virus can be inhibited by antibody, but only of the IgM class [70].

\section{Macrophage Responses to Viruses and Virus-Transformed Cells}

It is well established that macrophages are an essential component of the host's cellular immune response to several viruses. Johnson [53] showed that in mice, newborns were more susceptible to HSV dissemination than adults, and that resistance developed progressively from birth to about 28 days. Hirsch et al.[51] showed that newborn mice could be protected from intraperitoneal challenge with HSV by passive transfer of syngeneic adult macrophages. Proteose-peptone- 
stimulated macrophages were more efficient in conferring protection than unstimulated macrophages and also showed more efficient phagocytosis and greater interferon production. Macrophages from neonatal mice could not be stimulated by proteose-peptone. When the macrophages of adult mice were inactivated in vivo by administration of silica or anti-macrophage serum, HSV was then able to disseminate and cause early death $[25,151]$. Since macrophage depletion or immaturity can cause susceptibility to HSV, resistance to the virus should be increased by macrophage stimulants. This has been shown to be true in several independent laboratories.

The macrophage stimulant, $\mathrm{BCG}$, can increase the resistance of adult mice to intravaginal inoculation of HSV, if given in combination with HSV antiserum [4]. In rabbits, BCG alone can decrease the mortality after corneal or intravaginal infection with HSV type 2 (HSV-2) [64].

HSV is readily taken up by macrophages in vitro, and infected macrophages from newborn, but not adult, mice are able to infect surrounding cells [53]. The titer of virus produced in suckling mouse macrophages is higher than in adult mouse macrophages, which absorb 100 times more virus than those of suckling mice [51]. Infected macrophages were found by Stevens and Cook [126] to synthesize virus proteins and nucleic acids but not to permit proper assembly of infective virions. Lodmell et al. [72] showed that infection of a monolayer of rabbit kidney cells by HSV could be inhibited by peritoneal exudate cells from nonimmune rabbits. No soluble mediators were detected and it was assumed that the effect was due to activated macrophages disrupting cell-to-cell contacts and so preventing virus spread. It was also demonstrated that virus multiplication within the infected cells was inhibited by the presence of macrophages, but the mechanism of this remained unclear. The degree of HSV restriction by macrophages in vitro was shown by Mogensen [83] to be related to whether the macrophages were from strains resistant to or susceptible to the virus in vivo. The virus replicated equally well in fibroblasts from resistant or susceptible strains, indicating that the observed genetic influence on susceptibility may be mediated through macrophage functions.

Intraperitoneal injection of HSV-2 into mice led to large progressive foci and infection in the liver, while HSV type 1 (HSV-1) induced occasional small, selfhealing foci [84]. This was well correlated with infectious-center assays in peritoneal macrophages: HSV-2 produced 17 times as many infectious centers as HSV-1, and the HSV-2 plaques were large and increased, while those of HSV-1 were small and regressed. Further evidence that the in vivo differences in the results of HSV-type infections was macrophage-mediated was found when inactivation of macrophages in vivo by administration of silica abolished the difference in hepatotropism of HSV -1 and HSV-2, as assessed by the number and size of lesions appearing in the liver [85].

Morahan et al. [89] showed that activation of mouse macrophages in vivo by administration of C. parvum, C.acne, or pyran reduced the mortality rate following HSV infection, while conversely, inactivation of macrophages by silica increased susceptibility to the virus. In vitro, it was shown that macrophages obtained from mice given corynebacteria or pyran in vivo exhibited antiviral activity when compared to macrophages from unstimulated animals. This was not virus-specific 
since herpes simplex, vaccinia, and encephalomyocarditis viruses were all inactivated.

In addition to the control of virus infections, macrophages have been demonstrated to be important in the immune response against tumor cells, including those induced by oncogenic viruses. The balance between regression or progression of leukemia in mice infected with the RFV strain of Friend virus was shown by Marcelletti and Furmanski [78] to be closely determined by macrophages. This particular strain of virus induces leukemia that regresses spontaneously in about half the infected animals, with return of normal spleen size and histology, and loss of detectable virus from the spleen and peripheral blood. The immune system was shown to be involved in the spontaneous regression since immunosuppression by thymectomy or anti-thymocyte serum converted the regressing pattern to a progressing one [21] while immunostimulation with inactivated leukemic cells and BCG increased regression [50]. The spontaneous regression was shown to be macrophage-dependent as suppression or elimination of macrophages in leukemic mice by silica, carrageenan, anti-macrophage serum, or trypan blue decreased the number of animals showing regression. It was found that leukemic mice with normal macrophage phagocytic activity regressed, while those in which the virus had suppressed phagocytosis did not. Progressor mice could be induced to regress by passive transfer of normal syngeneic macrophages, while passive transfer of other cell types was ineffective [78].

\section{Conclusions}

This brief review has concentrated on some current research topics in the field of surface antigens of virus-infected and virus-transformed cells, and on the host's cellular response to those antigens. Interactions exist between different elements of the cellular response (Fig. 4) and in addition, several mechanisms of humoral

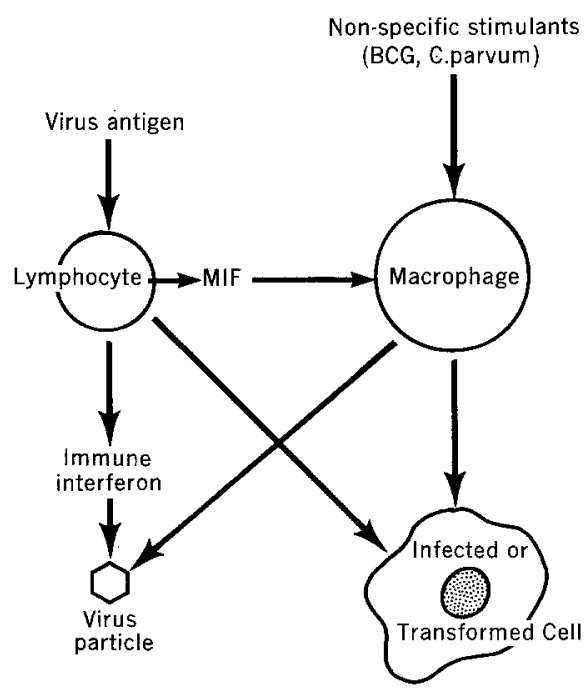

Fig. 4. Summary of pathways by which cellmediated immunity may lead to virus inactivation, or lysis of infected or transformed cells. Experimental evidence for each pathway and the virus infections in which it has been demonstrated are described in the text 
immunity have been investigated and are reviewed elsewhere in this volume. Interactions between humoral and cellular immunity are also important and it is also clear that the nature of immune responses to one virus, or in one species, cannot be easily transposed to any other situation.

Future problems in these areas are numerous. The apparent lack of antigens in slow viruses is a subject requiring investigation, particularly in view of the current interest in these agents as possible causes of chronic human diseases. The existence of recurrent virus infections, such as HSV, or persistent infections, such as in subacute sclerosing panencephalitis or with hepatitis B virus, has not been fully explained. Finally, the possible involvement of herpes-type viruses in human cancers makes their antigens of particular interest. If a herpesvirus-related transplantation antigen could be shown to exist, then specific immunotherapy for these cancers could be predicted. In fact, the apparent lack of transplantation antigens on cells transformed by herpesviruses is a subject requiring much closer study.

Acknowledgments. E. J. S. was a Leukemia Society of America Fellow. Original work described in this review was supported by contract NO1-CP-53516 within the Virus Cancer Program of the National Cancer Institute and grant CA 18450 awarded by the National Cancer Institute.

\section{References}

1. Albrecht, T., Rapp, F.: Malignant transformation of hamster embryo fibroblasts following exposure to ultraviolet-irradiated human cytomegalovirus. Virology 55, 53 (1973)

2. Albrecht, P., Burnstein, T., Klutch, M. J., Hicks, J. T., Ennis, F. A.: Subacute sclerosing panencephalitis: Experimental infection in primates. Science 195, 64 (1977)

3. Andersson, T., Stejskal, V., Harfast, B.: An in vitro method for study of human lymphocyte cytotoxicity against mumps-virus-infected target cells. J. Immunol. 114, 237 (1975)

4. Baker, M. B., Larson, C. L., Ushijima, R. N., Anderson, F. D.: Resistance of female mice to vaginal infection induced by Herpesvirus hominis type 2: Effects of immunization with $M$ ycobacterium bovis, intravenous injection of specific Herpesvirus hominis type 2 antiserum, and a combination of these procedures. Infect. Immun. 10, 1230 (1974)

5. Bansal, S. C., Hargreaves, R., Sjögren, H. O.: Facilitation of polyoma tumor growth in rats by blocking sera and tumor eluate. Int. J. Cancer 9, 97 (1972)

6. Bansal, S. C., Sjögren, H. O.: 'Unblocking' serum activity in vitro in the polyoma system may correlate with antitumour effects of antiserum in vivo. Nature 233, 76 (1971)

7. Blanden, R. V., Doherty, P. C., Dunlop, M. B. C., Gardner, I. D., Zinkernagel, R. M., David, C. S.: Genes required for cytotoxicity against virus-infected target cells in $\mathrm{K}$ and $\mathrm{D}$ regions of $\mathrm{H}-2$ complex. Nature 254, 269 (1975)

8. Blank, K. J., Freedman, H. A., Lilly, F.: T-lymphocyte response to Friend virus-induced tumor cell lines in mice of strains congenic at H-2. Nature 260, 250 (1976)

9. Blasecki, J. W., Tevethia, S. S.: In vitro assay of cellular immunity to tumor-specific antigen(s) of virus-induced tumors by macrophage migration inhibition. J. Immunol. 110, 590 (1973)

10. Boyse, E. A., Stockert, E., Old, L. J.: Modification of the antigenic structure of the cell membrane by thymus-leukemia (TL) antibody. Proc. Natl. Acad. Sci. USA 58, 954 (1967)

11. Brier, A. M., Wohlenberg, C., Rosenthal, J., Mage, M., Notkins, A. L.: Inhibition or enhancement of immunological injury of virus-infected cells. Proc. Natl. Acad. Sci. USA 68, 3073 (1971)

12. Burns, W. H., Allison, A. C.: Surface antigens of virus-infected cells. In: Virus infection and the cell surface, Poste, G. and Nicolson, G. L., eds., p. 213. Amsterdam: Elsevier 1977

13. Cambridge, G., MacKenzie, J. S., Keast, D.: Cell-mediated immune response to influenza virus infections in mice. Infect. Immun. 13, 36 (1976) 
14. Cerottini, J.-C., Brunner, K. T.: Cell-mediated cytotoxicity, allograft rejection, and tumor immunity. Adv. Immunol. 18, 67 (1974)

15. Chalmer, J. E., MacKenzie, J. S., Stanley, N. F.: Resistance to murine cytomegalovirus linked to the major histocompatibility complex of the mouse. J. Gen. Virol, 37, 107 (1977)

16. Choppin, P. W., Compans, R. W.: The structure of influenza virus. In: The influenza viruses and influenza, Kilbourne, E. D., ed., p. 15. New York: Academic Press 1975

17. Coggin, J. H., Elrod, L. H., Ambrose, K. R., Anderson, N. G.: Induction of tumor-specific transplantation immunity in hamsters with cell fractions from adenovirus and SV40 tumor cells. Proc. Soc. Exp. Biol. Med. 132, 328 (1969)

18. Cone, R. E., Gershon, R. K., Askenase, P. W.: Nylon adherent antigen-specific rosette-forming T cells. J. Exp. Med. 146, 1390 (1977)

19. Cooper, M. D., Chase, H. P., Lowman, J. T., Krivit, W., Good, R. A.: Wiskott-Aldrich syndrome. An immunologic deficiency disease, involving the afferent limb of immunity. Am J. Med. 44, 499 (1968)

20. Defendi, V.: Effect of SV40 virus immunization on growth of transplantable SV40 and polyoma virus tumors in hamsters. Proc. Soc. Exp. Biol. Med. 113, 12 (1963)

21. Dietz, M., Furmanski, P., Clymer, R., Rich, M. A.: Effects of thymectomy and antithymocyte serum on spontaneous regression of Friend virus-induced erythroleukemia. J. Natl. Cancer Inst. 57, 91 (1976)

22. Doherty, P.C., Blanden, R. V.,Zinkernagel, R. M.: Specificity of virus-immune effector T cells for H$2 \mathrm{~K}$ or $\mathrm{H}-2 \mathrm{D}$ compatible interactions: Implications for $\mathrm{H}$-antigen diversity. Transplant. Rev. 29, 89 (1976)

23. Doherty, P. C., Zinkernagel, R. M.: H-2 compatibility is required for T-cell-mediated lysis of target cells infected with lymphocytic choriomeningitis virus. J. Exp. Med. 141, 502 (1975)

24. Dolin, R., Murphy, B. R., Caplan, E. A.: Lymphocyte blastogenic responses to influenza virus antigens after influenza infection and vaccination in humans. Infect. Immun. 19, 867 (1978)

25. Du Buy, H.: Effect of silica on virus infections in mice and mouse tissue culture. Infect. Immun. 11, $996(1975)$

26. Duff, R., Doller, E., Rapp, F.: Immunologic manipulation of metastases due to herpesvirus transformed cells. Science 180, 79 (1973)

27. Duff, R., Rapp, F.: Reaction of serum from pregnant hamsters with surface of cells transformed by SV40. J. Immunol. 105, 521 (1970)

28. Dupont, B., Hansen, J. A., Yunis, E. J.: Human mixed-lymphocyte culture reaction: Genetics, specificity, and biological implications. Adv. Immunol. 23, 107 (1976)

29. Eckert, E. A.: Properties of an antigenic glycoprotein isolated from influenza virus hemagglutinin. J. Virol. 11, 183 (1973)

30. Eddy, B. E., Borman, G. S., Grubbs, G. E., Young, R. D.: Identification of the oncogenic substance in Rhesus monkey kidney cell cultures as simian virus 40. Virology 17, 65 (1962)

31. Effros, R. B., Doherty, P. C., Gerhard, W., Bennink, J.: Generation of both cross-reactive and virusspecific T-cell populations after immunization with serologically distinet influenza A viruses. J. Exp. Med. 145, 557 (1977)

32. El Araby, I. I., Chernesky, M. A., Rawls, W. E., Dent, P. B.: Depressed herpes simplex virus-induced lymphocyte b'astogenesis in individuals with severe recurrent herpes infections. Clin. Immunol. Immunopathol. 9, 253 (1978)

33. Ennis, F. A., Martin, W. J., Verbonitz, M. W.: Cytotoxic T lymphocytes induced in mice by inactivated influenza virus vaccine. Nature 269, 418 (1977)

34. Ewan, P. W., Lachmann, P. J.: Demonstration of T-cell and K-cell cytotoxicity against measlesinfected cells in normal subjects, multiple sclerosis and subacute sclerosing panencephalitis. Clin. Exp. Immunol. 30, 22 (1977)

35. Feinstone, S. M., Beachey, E. H., Rytel, M. W.: Induction of delayed hypersensitivity to influenza and mumps viruses in mice. J. Immunol. 103, 844 (1969)

36. Fujibayashi, T., Hooks, J. J., Notkins, A. L.: Production of interferon by immune lymphocytes exposed to herpes simplex virus-antibody complexes. J. Immunol. 115, 1191 (1975)

37. Fulginiti, V. A., Kempe, C. H., Hathaway, W. E., Pearlman, D. S., Sieber, O. F., Eller, J. J., Joyner, A. D., Robinson, A.: Progressive vaccinia in immunologically deficient individuals. Birth Defects 4, 129 (1968)

38. Gadol, N., Johnson, J. E. III, Waldman, R. H.: Respiratory tract cell-mediated immunity: Comparison of primary and secondary response. Infect. Immun. 9, 858 (1974) 
39. Gardner, I. O., Bower, N. A., Blanden, R. V.: Cell-mediated cytotoxicity against ectromelia virusinfected target cells. III. Role of the H-2 gene complex. Eur. J. Immunol. 5, 122 (1975)

40. Garrido, F., Schirrmacher, V., Festenstein, H.: H-2-like specificities of foreign haplotypes appearing on a mouse sarcoma after vaccinia virus infection. Nature 259, 228 (1976)

41. Gerber, P., Lucas, S. J.: In vitro stimulation of human lymphocytes by Epstein-Barr virus. Cell Immunol. 5, 318 (1972)

42. Girardi, A. J., Sweet, B. H., Slotnick, V. B., Hilleman, M. R.: Development of tumors in hamsters inoculated in the neonatal period with vacuolating virus, SV40. Proc. Soc. Exp. Biol. Med. 109, 649 (1962)

43. Greenberg, S. B., Criswell, B. S., Couch, R. B.: Lymphocyte-mediated cytotoxicity against influenza virus-infected cells: An in vitro method. J. Immunol. 115, 601 (1975)

44. Habel, K., Eddy, B.: Specificity of resistance to tumor challenge of polyoma and SV40 virusimmune hamsters. Proc. Soc. Exp. Biol. Med. 113, 1 (1963)

45. Hahon, N., Eckert, H. L.: Cell surface antigen induced by influenza virus. Infect. Immun. 6, 730 (1972)

46. Halliday, W. J.: Macrophage migration inhibition with mouse tumor antigens: Properties of serum and peritoneal cells during tumor growth and after tumor loss. Cell. Immunol. 3, 113 (1972)

47. Hayry, P., Defendi, V.: Surface antigen(s) of SV40-transformed tumor cells. Virology 41, 22 (1970)

48. Hellman, A., Fowler, A. K., Steinman, H. G., Buzzard, P. M.: Studies of the blastogenic response of murine lymphocyte. III. Specific viral transformation. Proc. Soc. Exp. Biol. Med. 141, 106 (1972)

49. Hellström, K. E., Hellström, I.: Immunological enhancement as studied by cell culture techniques. Ann. Rev. Microbiol. 24, 373 (1970)

50. Hines, D. L., Dietz, M., Furmanski, P., Rich, M. A.: Alteration of Friend virus induced erythroleukemia by active immunotherapy and antithymocyte serum. Proc. Am. Assoc. Cancer Res. 18, 185 (1977)

51. Hirsch, M. S., Zisman, B., Allison, A. C.: Macrophages and age-dependent resistance to herpes simplex virus in mice. J. Immunol. 104, 1160 (1970)

52. Ito, M., Barron, A. L.: Surface antigen produced by herpes simplex virus (HSV). J. Immunol. 108, $711(1972)$

53. Johnson, R. T.: The pathogenesis of herpes virus encephalitis. II. A cellular basis for the development of resistance with age. J. Exp. Med. 120, 359 (1964)

54. Joseph, B. S., Oldstone, M. B. A.: Antibody-induced redistribution of measles virus antigens on the cell surface. J. Immunol. 113, 1205 (1974)

55. Khera, K. S., Ashkenazi, A., Rapp, F., Melnick, J. L.: Immunity in hamsters to cells transformed in vitro and in vivo by SV40. Tests for antigenic relationship among the papovaviruses. J. Immunol. 91, 604 (1963)

56. Kilbourne, E. D.: In: The Influenza viruses and influenza, Kilbourne, E. D., ed., p. 483. New York: Academic Press 1975

57. Klein, J.: Biology of the mouse histocompatibility complex. New York: Springer-Verlag 1975

58. Koch, M. A., Sabin, A.: Specificity of virus-induced resistance to transplantation of polyoma and SV40 tumours in adult hamsters. Proc. Soc. Exp. Biol. Med. 113, 4 (1963)

59. Koszinowski, U., Ertl, H.: Lysis mediated by T cells and restricted by H-2 antigen of target cells infected with vaccinia virus. Nature 255, 552 (1975)

60. Koszinowski, U., Thomssen, R.: Target cell-dependent T cell-mediated lysis of vaccinia virusinfected cells. Eur. J. Immunol. 5, 245 (1975)

61. Koyama, H., Kasahara, S., Akiyama, T.: Migration inhibition test in mice inoculated with herpes simplex virus. Kitasato Arch. Exp. Med. 47, 63 (1974)

62. Labowskie, R. J., Edelman, R., Rustigian, R., Bellanti, J. A.: Studies of cell-mediated immunity to measles virus by in vitro lymphocyte-mediated cytotoxicity. J. Infect. Dis. 129, 233 (1974)

63. Lampert, P. W., Joseph, B. S., Oldstone, M. B. A.: Antibody-induced capping of measles virus antigens on plasma membrane studied by electron microscopy. J. Virol. 15, 1248 (1975)

64. Larson, C. L., Ushijima, R. N., Karim, R., Baker, M. B., Baker, R. E.: Herpesvirus hominis type 2 infections in rabbits: Effects of prior immunization with attenuated Mycobacterium bovis (BCG) cells. Infect. Immun. 6, 465 (1972)

65. Lausch, R. N., Jones, C., Christie, D., Hay, K. A., Rapp, F.: Spleen cell-mediated cytotoxicity of hamster cells transformed by herpes simplex virus: Evidence for virus-specific membrane antigen. J. Immunol. 114, 459 (1975) 
66. Lausch, R. N., Murasko, D. M., Albrecht, T., Rapp, F.: Detection of specific surface antigens on cells transformed by cytomegalovirus with the techniques of mixed hemagglutination and ${ }^{125} \mathrm{I}$-labeled antiglobulin. J. Immunol. 112, 1680 (1974)

67. Lausch, R. N., Murasko, D. M., Hay, K. A.: Tumor cell survival in a hostile immune environment. In: Fundamental aspects of metastasis, Weiss, L., ed., p. 327. Amsterdam: North-Holland Publishing Company 1976

68. Lausch, R. N., Sofranko, J., Prather, S. O.: Analysis of sera from SV40-immunized and tumorbearing hosts for blocking activity and antibody-dependent cellular cytotoxicity. J. Immunol. 115, $682(1975)$

69. Laver, W.G., Webster, R. G.: Studies on the origin of pandemic influenza. III. Evidence implicating duck and equine influenza viruses as possible progenitors of the Hong Kong strain of human influenza. Virology 51, 383 (1973)

70. Lee, J.C., Sigel, M. M.: A differential effect of IgM and IgG antibodies on the blastogenic response of lymphocytes to rubella virus. Cell Immunol. 13, 22 (1974)

71. Lilly, F.: The effect of histocompatibility-2 type on response to the Friend leukemia virus in mice. J. Exp. Med. 127, 465 (1968)

72. Lodmell, D. L., Niwa, A., Hayashi, K., Notkins, A. L.: Prevention of cell-to-cell spread of herpes simplex virus by leukocytes. J. Exp. Med. 137, 706 (1973)

73. Lodmell, D. L., Notkins, A. L.: Cellular immunity to herpes simplex virus mediated by interferon. J. Exp. Med. 140, 764 (1974)

74. Löffler, H., Henle, G., Henle, W.: Attempts to influence the incomplete reproductive cycle of influenza virus in HeLa cells by antibodies. J. Immunol. 88, 763 (1961)

75. Longenecker, B. M., Pazderka, F., Gavora, J. S., Spencer, J. L., Ruth, R. F.: Lymphoma induced by herpesvirus: Resistance associated with a major histocompatibility gene. Immunogenetics 3, 401 (1976)

76. Lopez, $C$ : Genetics of natural resistance to herpesvirus infections in mice. Nature 258, 152 (1975)

77. Lux, S. E., Johnson, R. B. Jr., August, C. S., Say, B., Perchaszadeh, V. B., Rosen, F. S., McK usick, V. A.: Chronic neutropenia and abnormal cellular immunity in cartilage-hair hypoplasia. N. Engl. J. Med. 282, 231 (1970)

78. Marcelletti, J., Furmanski, P.: Spontaneous regression of Friend virus-induced erythroleukemia. III. The role of macrophages in regression. J. Immunol. 120, 1 (1978)

79. Medical Research Council: Hypogammaglobulinaemia in the United Kingdom. M. R. C. Special Report Series No. 310, London: H. M. Stationary Office 1971

80. Meyers, R. L., Pettit, T. H.: Corneal immune response to herpes simplex virus antigens. J. Immunol. 110, $1575(1973)$

81. Miller, M. E., Schieken, R. M.: Thymic dysplasia: A separable entity from Swiss agammaglobulinemia. Am. J. Med. Sci. 253, 741 (1967)

82. Minson, A. C., Thouless, M. E., Eglin, R. P., Darby, G.: The detection of virus DNA sequences in a herpes type 2 transformed hamster cell line (333-8-9). Int. J. Cancer 17, 493 (1976)

83. Mogensen, S. C.: Genetics of macrophage-controlled resistance to hepatitis induced by herpes simplex virus type 2 in mice. Infect. Immun. 17, 268 (1977)

84. Mogensen, S.: Role of macrophages in hepatitis induced by herpes simplex virus types 1 and 2 in mice. Infect. Immun. 15, 686 (1977)

85. Mogensen, S. C., Andersen, H. K.: Effect of silica on the pathogenic distinction between herpes simplex virus type 1 and 2 hepatitis in mice. Infect. Immun. 17, 274 (1977)

86. Moller-Larsen, A., Andersen, H. K., Heron, I., Sarov, I.: In vitro stimulation of human lymphocytes by purified cytomegalovirus. Intervirology 6, $249(1975 / 76)$

87. Moller-Larsen, A., Heron, I., Haahr, S.: Cell-mediated cytotoxicity to herpes-infected cells in humans: Dependence on antibodies. Infect. Immun. 16, 43 (1977)

88. Morag, A., Beutner, K. R., Morag, B., Ogra, P. L.: Development and characteristics of in vitro correlates of cellular immunity to rubella virus in the systemic and mucosal sites in guinea pigs. J. Immunol. 113, 1703 (1974)

89. Morahan, P. S., Kern, E. R., Glasgow, L. A.: Immunomodulator $=$ induced resistance against herpes simplex virus. Proc. Soc. Exp. Biol. Med. 154, 615 (1977)

90. Murasko, D. M., Lausch, R. N.: Cellular immune response to virus-specific antigen in hamsters bearing isografts of cytomegalovirus-transformed cells. Int. J. Cancer 14, 451 (1974) 
91. Murasko, D. M., Lausch, R. N.: Spleen cell cytotoxicity for cytomegalovirus-transformed cells. II. Inhibition by cytomegalovirus antiserum Int. J. Cancer 16, 24 (1975)

92. Nathan, C. F., Remold, H. G., David, J. R.: Characterization of a lymphocyte factor which alters macrophage functions. J. Exp. Med. 137, 275 (1973)

93. Nordal, H. J., Fr $\phi$ land, S. S., Vandvik, B., Norrby, E.: Measles-virus-induced migration inhibition of human leucocytes: An immunologically unspecific phenomenon? Lancet ii, 1266 (1975)

94. Oakes, J. E.: Role for cell mediated immunity in the resistance of mice to subcutaneous herpes simplex virus infection. Infect. Immun. 12, 166 (1975)

95. Old, L. J., Stockert, E., Boyse, E. A., Kim, J.H.: Antigenic modulation. Loss of TL antigen from cells exposed to TL antibody. Study of the phenomenon in vitro. J. Exp. Med. 127, 523 (1968)

96. Oldstone, M. B. A., Tishon, A.: Immunologic injury in measles virus infection. IV. Antigenic modulation and abrogration of lymphocyte lysis of virus-infected cells. Clin. Immunol. Immunopathol. 9, 55 (1978)

97. O'Reilly, R. J., Chibbaro, A., Anger, E., Lopez, C.: Cell-mediated immune responses in patients with recurrent herpes simplex infections. II. Infection-associated deficiency of lymphokine production in patients with recurrent herpes labialis or herpes progenitalis. J. Immunol. 118, 1095 (1977)

98. Pfizenmaier, K., Jung, H., Starzinski-Powitz, A., Röllinghoff, M., Wagner, H.: The role of T cells in anti-herpes simplex virus immunity. I. Induction of antigen-specific cytotoxic T lymphocytes. $\mathrm{J}$. Immunol. 119, 939 (1977)

99. Prather, S. O., Lausch, R. N.: Membrane-associated antigen from the SV40-induced hamster fibrosarcoma, PARA-7. I. Role in immune complex formation and effector cell blockade. Int. J. Cancer 18, 820 (1976)

100. Rager-Zisman, B., Allison, A. C.: The role of antibody and host cells in the resistance of mice against infection by coxsackie B-3 virus. J. Gen. Virol. 19, 329 (1973)

101. Rager-Zisman, B., Allison, A. C.: Mechanism of immunologic resistance to herpes simplex virus 1 (HSV-1) infection. J. Immunol. 116, 35 (1976)

102. Ramshaw, I. A.: Lysis of herpesvirus-infected target cells by immune spleen cells. Infect. Immun. 11, $767(1975)$

103. Rasmussen, L. E., Jordan, G. W., Stevens, D. A., Merigan, T. C.: Lymphocyte interferon production and transformation after herpes simplex infections in humans. J. Immunol. 112, 728 (1974)

104. Reif, J. S., Lief, F. S., McGrath, J. T.: Local and systemic cell-mediated immunity in viral infection of the canine respiratory tract. Transplant. Proc. 7, 561 (1975)

105. Rola-Pleszczynski, M., Hurtardo, R. C., Woody, J. N., Sell, K. W., Vincent, M. M., Hensen, S. A., Bellanti, J. A.: Identification of the cell population involved in viral-specific cell-mediated cytotoxicity in man: Evidence for T cell specificity. J. Immunol. 115, 239 (1975)

106. Rosenberg, G. L., Farber, P. A., Notkins, A. L.: In vitro stimulation of sensitized lymphocytes by herpes simplex virus and vaccinia virus. Proc. Natl. Acad. Sci. USA 69, 756 (1972)

107. Rosenberg, G. L., Notkins, A. L.: Induction of cellular immunity to herpes simplex virus: Relationship to the humoral immune response. J. Immunol. 112, 1019 (1974)

108. Rosenberg, G. L., Snyderman, R., Notkins, A. L.: Production of chemotactic factor and lymphotoxin by human leukocytes stimulated with herpes simplex virus. Infect. Immun. 10, 111 (1974)

109. Russell, A. S., Maini, R. A., Bailey, M., Dumonde, D. C.: Cell-mediated immunity to varicella-zoster antigen in acute herpes zoster (shingles). Clin. Exp. Immunol. 14, 181 (1972)

110. Schild, G. C., Dowdle, W. R.: Influenza virus characterization and diagnostic serology. In: The influenza viruses and influenza, Kilbourne, E. D., ed., p. 315. New York: Academic Press 1975

111. Schrader, J. W., Cunningham, B. A., Edelman, G. M.: Functional interactions of viral and histocompatibility antigens at tumor cell surfaces. Proc. Nat1. Acad. Sci. USA 72, 5066 (1975)

112. Schulze, I. T.: The biologically active proteins of influenza virus: The hemagglutinin. In: The influenza viruses and influenza, Kilbourne, E. D., ed., p. 53. New York: Academic Press 1975

113. Schwartz, J., Elizan, T. S.: Altered immunologic specificity of cells infected with herpes simplex virus: Recognition by human antiserum. Z. Immunitaetsforsch. 148, 291 (1975)

114. Scriba, M.: Stimulation of peripheral blood lymphocytes by herpes simplex virus in vitro. Infect. Immun. 10, 430 (1974)

115. Shillitoe, E. J., Wilton, J. M. A., Lehner, T.: Sequential changes in cell-mediated immune responses to herpes simplex virus after recurrent herpetic infection in humans. Infect. Immun. 18, 130 (1977)

116. Shillitoe, E. J., Wilton, J. M. A., Lehner, T.: Sequential changes in cell-mediated immune responses 
to herpes simplex virus following primary herpetic infection in man. In: Oncogenesis and herpesviruses, de Thé, G., Henle, W., Rapp, F., eds., Lyon, France, Proceedings of the Symposium on Oncogenesis and Herpesviruses, IARC, 1979

117. Shillitoe, E. J., Wilton, J. M. A., Lehner, T.: Responses to herpes simplex virus of unfractionated lymphocytes, and T and B lymphocytes, in man. Scand. J. Immunol. 7, 357 (1978)

118. Simmons, R. L., Centifanto, Y., Kaufman, H. E.: Plaque size reduction as a measure of viral cellmediated immunity. Infect. Immun. 10; 1034 (1974)

119. Simons, M. J., Fitzgerald, M. G.: Rubella virus and human lymphocytes in culture. Lancet ii, 937 (1968)

120. Sjögren, H. O.: Transplantation methods as a tool for detection of tumor-specific antigens. Prog. Exp. Tumor Res. 6, 289 (1965)

121. Sjögren, H. O., Borum, K.: Tumor specific immunity in the course of primary polyoma and Rous tumor development in intact and immunosuppressed rats. Cancer Res. 31, 890 (1971)

122. Smith, R. W., Morganroth, J., Mora, P. T.: SV40 virus-induced tumour specific transplantation antigen in cultured mouse cells. Nature 227, 141 (1970)

123. Smith, K. A., Chess, L., Mardiney, M. R. Jr.: The characteristics of lymphocyte tritiated thymidine incorporation in response to mumps virus. Cell Immunol. 5, 597 (1972)

124. Stackpole, C. W., Jacobson, J. B., Lardis, M. P.: Antigenic modulation in vitro. I. Fate of thymusleukemia (TL) antigen-antibody complexes following modulation of TL antigenicity from the surfaces of mouse leukemia cells and thymocytes. J. Exp. Med. 140, 939 (1974)

125. Steele, R. W., Vincent, M. M., Hensen, S. A., Fuccillo, D. A., Chapa, I. A., Canales, L.: Cellular immune responses to herpes simplex virus type 1 in recurrent herpes labialis: In vitro blastogenesis and cytotoxicity to infected cell lines. J. Infect. Dis. 131, 528 (1975)

126. Stevens, J. G., Cook, M. L.: Restriction of herpes simplex virus by macrophages. An analysis of the cell-virus interaction. J. Exp. Med. 133, 19 (1971)

127. Stevens, J. G., Cook, M. L.: Maintenance of latent herpetic infection: An apparent role for anti-viral IgG. J. Immunol. 113, 1685 (1974)

128. Sweet, B. H., Hilleman, M. R.: The vacuolating virus, SV40. Proc. Soc. Exp. Biol. Med. 105, 420 (1960)

129. Taylor, R. B., Duffus, W. P. H., Raff, M. C., de Petris, S.: Redistribution and pinocytosis of lymphocyte surface immunoglobulin molecules ind uced by anti-immunoglobulin antibody. Nature 233, 225 (1971)

130. Ten Napel, C. H. H., The, T. H., Bijker, J., De Gast, G. C., Langenhuysen, M. M. A. C.: Cytomegalovirus-directed lymphocyte reactivity in healthy adults tested by a CMV-induced lymphocyte transformation test. Clin. Exp. Immunol. 29, 52 (1977)

131. Tevethia, S. S., Crouch, N. A., Melnick, J. L., Rapp, F.: Detection of specific surface antigens by colony inhibition in cells transformed by papovavirus SV40. Int. J. Cancer 5, 176 (1970)

132. Tevethia, S. S., Katz, M., Rapp, F.: New surface antigen in cells transformed by simian papovavirus SV40. Proc. Soc. Exp. Biol. Med. 119, 896 (1965)

133. Thiry, L., Sprecher-Goldberger, S., Tack, L., Jacques, M., Stienon, J.: Comparison of the immunogenicity of hamster cells transformed by adenovirus and herpes simplex virus. Cancer Res. 35, $1022(1975)$

134. Thompson, R. L., Sande, M. A., Wenzel, R. P., Hoke, C. H, Jr., Gwaltney, J. M. Jr.: Swine-influenza infection in civilians. N. Engl. J. Med. 295, 714 (1976)

135. Thong, Y. H., Hensen, S. A., Vincent, M. M., Fuccillo, D. A., Stiles, W. A., Bellanti, J. A.: Use of cryopreserved virus-infected target cells in a lymphocytotoxicity ${ }^{51} \mathrm{Cr}$ release microassay for cellmediated immunity to cytomegalovirus. Infect. Immun. 13, 643 (1976)

136. Ting, C. C., Lavrin, D. H., Shiu, G., Herberman, R. B.: Expression of fetal antigens in tumor cells. Proc. Natl. Acad. Sci. USA 69, 1664 (1972)

137. Trinchieri, G., Aden, D. P., Knowles, B. B.: Cell-mediated cytotoxicity to SV40-specific tumourassociated antigens. Nature 261, 312 (1976)

138. Tursz, T., Fridman, W. H., Senik, A., Tsapis, A., Fellous, M.: Human virus-infected target cells lacking HLA antigens resist specific T-lymphocyte cytolysis. Nature 269, 806 (1977)

139. Unanue, E. R., Karnovsky, M. J.: Redistribution and fate of Ig complexes on surface of $B$ lymphocytes: Functional implications and mechanisms. Transplant. Rev. 14, 184 (1973)

140. Utermohlen, V., Zabriskie, J. B.: A suppression of cellular immunity in patients with multiple sclerosis. J. Exp. Med. 138, 1591 (1973) 
141. Valle, M. J., Bobrove, A. M., Strober, S., Merigan, T. C.: Immune specific production of interferon by human $T$ cells in combined macrophage-lymphocyte cultures in response to herpes simplex antigen. J. Immunol. 114, 435 (1975 a)

142. Valle, M. J., Jordan, G. W., Haahr, S., Merigan, T. C.: Characteristics of immune interferon produced by human lymphocyte cultures compared to other human interferons. J. Immunol. 115, 230 (1975b)

143. Waldman, R. H., Spencer, C. S., Johnson, J. E. III : Respiratory and systemic cellular and humoral immune responses to influenza virus vaccine administered parenterally or by nose drops. Cell Immunol. 3, 294 (1972)

144. Wear, D. J., Rapp, F.: Latent measles virus infection of the hamster central nervous system. J. Immunol. 107, 1593 (1971)

145. Webster, R. G., Campbell, C. H., Granoff, A.: The 'in vivo' production of 'new' influenza viruses. III. Isolation of recombinant influenza viruses under simulated conditions of natural transmission. Virology 51, 149 (1973)

146. Wetherbee, R. E.: Induction of systemic delayed hypersensitivity during experimental viral infection of the respiratory tract with a myxovirus or paramyxovirus. J. Immunol. 111, 157 (1973)

147. White, D. O.: Influenza viral proteins: Identification and synthesis. Curr. Top. Microbiol. Immunol. 63, 1 (1974)

148. Zaia, J. A., Palmer, E. L., Feorino, P. M.: Humoral and cellular immune responses to an envelopeassociated antigen of herpes simplex virus. J. Infect. Dis. 132, 660 (1975)

149. Zhdanov, V. M., Lvov, D. K., Zakstelskaya, L. Y., Yakhno, M. A., Isachenko, V. I., Braude, N. A., Reznik, V. I., Pysina, T. V., Andreyev, V.P., Podchernyaeva, R. Y.: Return of epidemic A1 (H1N1) influenza virus. Lancet $\mathbf{i}, 294$ (1978)

150. Zinkernagel, R. M., Doherty, P. C.: Restriction of in vitro T cell-mediated cytotoxicity in lymphocytic choriomeningitis within a syngeneic or semiallogeneic system. Nature 248, 701 (1974)

151. Zisman, B., Hirsch, M. S., Allison, A. C.: Selective effects of anti-macrophage serum, silica and antilymphocyte serum on pathogenesis of herpesvirus infections of young adult mice. J. Immunol. 104, $1155(1970)$

152. Zisman, B., Wheelock, E. F., Allison, A. C.: Role of macrophages and antibody in resistance of mice against yellow fever virus. J. Immunol. 107, 236 (1971)

153. Zweerink, H. J., Askonas, B. A., Millican, D., Courtneidge, S. A., Skehel, J. J.: Cytotoxic T cells to type A influenza virus; viral hemagglutinin induces A-strain specificity while infected cells confer cross-reactive cytotoxicity. Eur. J. Immunol. 7, 630 (1977) 